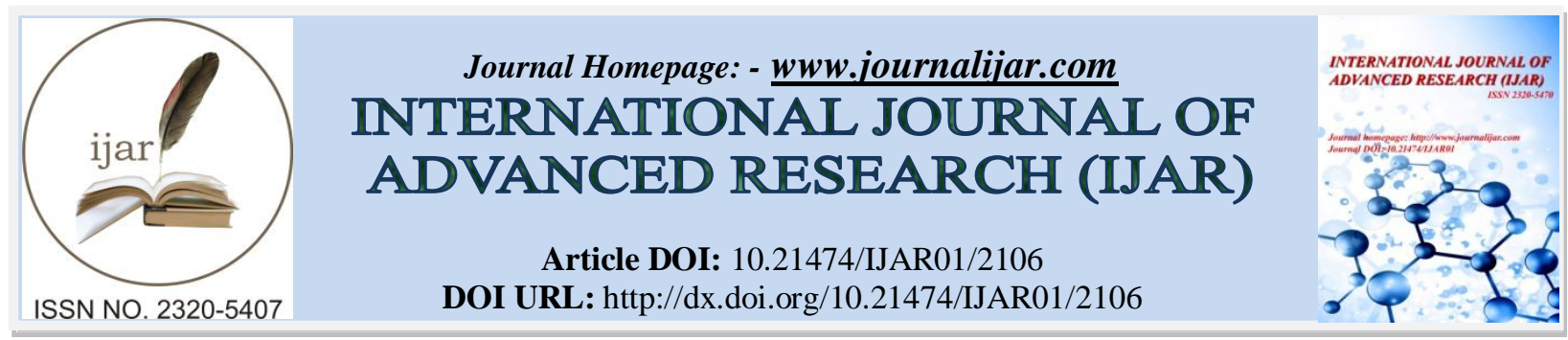

RESEARCH ARTICLE

\title{
SUSTAINABILITY DEVELOPMENT AND INNOVATION: WHAT LINKS THESE TWO CONCEPTS?
}

\author{
Abdelhaq lahfidi and M'Bark houssas. \\ National School of Management and Trades, IBN - ZOHR University, Agadir, MOROCCO.
}

\section{Manuscript Info}

Manuscript History

Received: 24 September 2016

Final Accepted: 26 October 2016

Published: November 2016

Key words:-

sustainable development, innovation,

Corporate Social Responsibility,

strategic dimension, environment

\begin{abstract}
For several years, the relationship between innovation and sustainable development has been the subject of some of work which has mainly focused on the innovation's environmental strategic dimensions (Temri 2011). Currently, the integration of sustainable development into business becomes an innovation generator factor (Mathieu and Soparnot, 2007). The objective of this research paper is to verify the nature of the relationship between these two concepts in the Moroccan context. To do this, a survey was conducted among a sample of 40 companies within different areas of the Souss Massa region. Through this study, we can confirm that there is a double link between innovation and sustainable development. Indeed, the establishment of sustainable development is positively related to innovation not only by innovating or not, but also by the number of innovations and the areas of innovation affected.
\end{abstract}

Copy Right, IJAR, 2016,. All rights reserved.

\section{Introduction:-}

Environmental changes, such as climate change and the scarcity of natural resources, in addition to social pressures imposed by the public opinion and the government allow having a context for mastering innovation opportunities (Abrassat and Aggeri, 2007). For Wernerfelt Barney (1984) and (1991), innovative strategies are considered as a guarantee of the sustainability of organizations regardless of their size. Sustainable development strategies represent opportunities with the objective of improving the overall performance that takes into consideration the social, economic and environmental aspects.

Currently, in terms of innovation, research has focused on large ambidextrous organizations able to reconcile operating innovation and exploration. However, the sector of small and medium sized businesses (SMEs) remain largely neglected by researchers despite its importance for the companies' strategic development.

The subject of our article is to examine how sustainable development strategy can be designed as a powerful driver of innovation for SMEs in the context of the Souss Massa region. Thus, first of all, we will deal with the relationship between sustainable development and innovation strategies. Next, we will focus on the empirical analysis of this relationship among SMEs in the Souss Massa region.

\section{Sustainable Development: Key Factor For Innovation Strategy: \\ Innovation: Strategic Concept:}

The innovation field is a new field even if research is relatively old. Thus, from a scientific point of view, innovation is a key factor in ensuring the performance of organizations (Foray and Mairesse, 1999). "The innovation activity is therefore of a strategic importance. It determines the capacity of the organization to outperform its competitors in 
the long term" (Soparnot and Stevens 2007). Innovation is seen as a source of competitive advantage for companies ( LengnickHall, 1992).

For several years, significant research has been conducted for understanding innovation without ambiguities (Carrier and Garand, 1996). Since the analysis of Schumpeter (1935), relations between innovation and performance are the subject of numerous studies in the literature, both on the micro and macro levels.

For Schumpeter, Innovation is conceived as the realization process of a new combination. In this context, the author distinguishes five different forms:

- The production of a new product;

- The establishment of a new method of production;

- The conquest of new markets ;

- The search for a new source of raw material ;

- The achievement of a new organization.

Starting from this excellent analysis of Schumpeter, one can say that innovation matches development and implementation of new ideas in a given organizational context (Van de Ven, 1986). For Kanter (1983), innovation is seen as a process allowing the use of new methods of problems resolution and the creation of new ideas. The evolutionary approach of innovation considers this one as a learning process. In addition, the evolutionary approach focuses on the middle of the innovation process, considering innovation in the firm without marginalizing its environment. Several forms of innovation exist, but the most used are the one based on the nature of innovation (product innovation, process innovation, market innovation and organizational innovation) Barreyre (1975) and the one based on the radical innovation (distinguishing breakthrough innovation and adaptation of the existing innovation) (Damanpour, 1991).

Although there are several forms of innovation, Schumpeter put much emphasis on the importance of the technological innovation.

The massive and growing introduction of sustainable development in the political and economic analyses triggered various discussions on the link between sustainable development and innovation (Mathieu, 2008). Several authors prefer to retain the term of environmental technologies as technologies guiding sustainable development. In this context, some authors as Patris and al. (2001) distinguish additive environmental technologies (driving to toxic emission reductions) integrated environmental technologies (concerned with a reduction at source of the negative impacts of products or processes on the environment)

·

At this analysis, innovation is a very important feature of management for generating performance. But the main question in this analysis is the bond that can exist between innovation and sustainable development.

Sustainable development: strategic vector for business:

Sustainable development is development that meets the needs of the present without compromising the ability of future generations to meet theirs. It should enable rational management of resources and ensure an effective balance between the three axes of economic, social and environmental (fields).

\section{Instruments objectives}

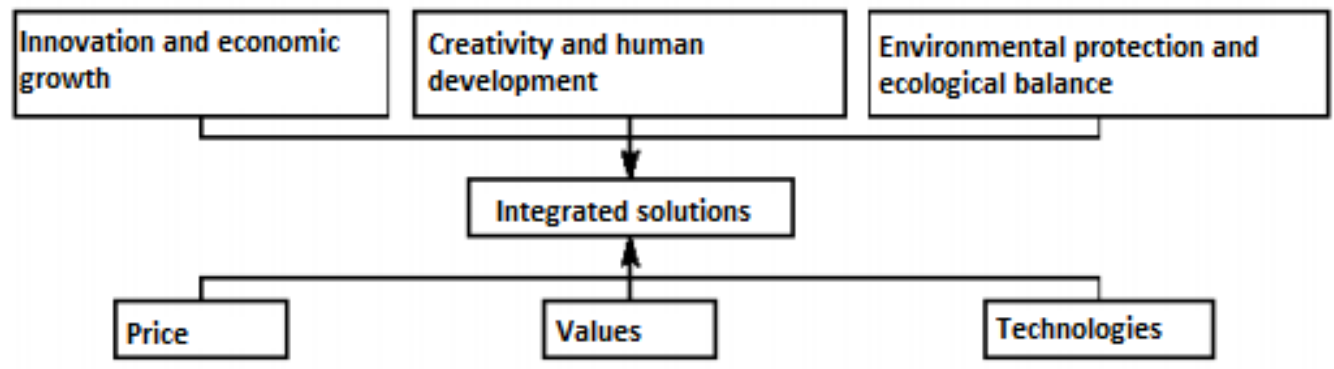

Source: A.Pulido, E. Fontela (2004) 
The diagram above shows the symbiotic relationship that should exist between the three aspects of sustainable development thereby conveys the innovation needed for better protection of the environment, Economic creativity and sustained human development.

The environment axis represents the main element of the strategy of sustainable development that aims to the protection of natural resources and the conservation of ecological processes. Ignoring this appearance is a serious problem and a real threat to the overall long-term competitiveness. So, for example, the concentration of industrial activity in a specific region can cause environmental degradation and natural areas.

So, to deal with these problems, it is highly recommended to promote a sustainability strategy respectful of the environment allowing the efficient use of resources. On the social plan, sustainable development seeks heritage protection.

\section{Links between sustainable development and innovation:}

In the literature, several configurations in terms of sustainable development strategy are identified. Thus, according to Bellini (2003), there are two types of sustainable development strategies. The first is part of an additive logic where the company does not question its decision process. The second is the systemic logic in which the integration of the environment completely changes the company's decision process. On this logic, three behaviors are distinguished:

Eco- defensive behaviors (lack of willingness to get involved from the leader because of insufficient financial and human resources). Eco- conformist behavior (Adaptive attitude to meet the standards imposed by the regulations). Ecologically- sensitive behavior or proactive that goes beyond current regulations by playing an innovative role in its industry.

Similarly, Mathieu (2008) tried to link these sustainable development strategies with existing environmental technologies in organizations. To this effect, the author distinguishes the approach Adaptive (eco - defensive), characterized by marginal environmental innovation, a pro- active approach (or eco - sensitive) that advances the company on the path to sustainable development (Hart, 1995). Pro-active strategies are largely ignored by companies because they require significant financial and human resources (Mathieu and Soparnot, 2007). Companies that adopt such strategy are essentially seeking long-term overall performance based on reducing costs, legitimacy and strategic differentiation from competitors.

Innovation, leverage of entrepreneurship: organizational ambidexterity:-

In the literature of management, the strategic development of SMEs depends mainly on innovation seen as a leverage of entrepreneurship (Aragon - Know -Martin, 2005). Thus, entrepreneurship is above all "a creative collective values, recognized by various actors who share the challenges and risks of innovation accepted by the market close, the middle and finally the outside" (Julien and Lachance (2006). Based on this definition, sustainable development is thus an integral part of entrepreneurial phenomenon. It allows the construction and operation of an opportunity as innovation, the creation of new organizations or value.

According to several researchers, the value creation is considered as a guarantee of sustainability and organizations' performance that rely on a balance between exploitation activities already mastered and exploring new paths. In fact, to be limited to the exploitation remains detrimental forward because it endangers the competitiveness of the organization. It is therefore appropriate to combine operational innovation and operating innovation (Chanaland Mothe (2005). Thus, the company can start projects that aim to design new products or Service (operating innovation) while creating new knowledge (exploration innovation). But this requires a certain dynamic ability which is to "detect and understand new opportunities to reconfigure and to protect the resources and expertise of the company, with the objective of gaining a competitive advantage" (Augier and Teece, 2009, p. 412). This reasoning leads us to the concept of organizational ambidexterity developed by Duncun, Gupta et al. (2006) which means the Simultaneous continuation operating and exploration targets. In other words, an ambidextrous organization is an organization that is able to reconcile between the two types of innovation (short-term operation and medium-term exploration). Indeed, such a combination is emerging as a must strategy for SMEs (Chanal and Mothe, 2005). Through this literature review, we aim to study the link between innovation and sustainable development in the Souss Massa region. 
Empirical study: Relationship between sustainable development and innovation in the SMEs of Souss Massa region:-

\section{Methodology:-}

Our goal is to make a study based on a survey of 40 SMEs in the Souss Massa region. This study aims at first to make an inventory on the dynamics of these companies. Based on the collected data, we try to make an analysis of innovation and sustainable development of SMEs. In this context, we first of all look at whether these companies are more focused on integration into a sustainable development approach. This study focuses on 40 companies surveyed along different axes including innovation and sustainable development. In this sense, various issues posed to business leaders and from this data we determined firstly a measuring innovation of these companies and also a measure of their integration into a process of sustainable development. To this end, the measure of innovation was developed on the basis of a score innovation (SC- IN). In view of the answers collected at the companies' level, these questions concern the 4 areas of innovation that are product innovation, process innovation, packaging innovation and organizational innovation. What distinguishes 5 categories $(0,1,2,3,4)$, the modality 0 means that during the last 4 years, the company has not made innovation . To explain innovation, we selected several variables including: the importance of sales, company size and the company's business.

On the other hand, the integration's measurement in the Souss Massa region in a process of sustainable development is also based on a score calculated based on the three strategic axes of sustainable development: the social axis, the economic axis and the environmental axis. For each axis, we selected specific variables to the Moroccan context (Table 1).

Table 1:- Variables used to measure the integration of SMEs into a process of sustainable development.

\begin{tabular}{|l|l|l|}
\hline The axis & The retained variables & Score \\
\hline \multirow{5}{*}{ Eccial } & $\begin{array}{l}\text { The existence of social measures } \\
(0,1,2)\end{array}$ & $/ 2$ \\
\cline { 2 - 3 } & $\begin{array}{l}\text { The implementation of the profit } \\
\text { sharing policy }\end{array}$ & $/ 1$ \\
\hline \multirow{4}{*}{ Environment } & $\begin{array}{l}\text { Existence of a "carrier" of a } \\
\text { sustainable development strategy }\end{array}$ & $/ 2$ \\
\cline { 2 - 3 } & Obtaining certifications & $/ 1$ \\
\cline { 2 - 3 } & $\%$ of the turn over & $/ 1$ \\
\hline Total & $\begin{array}{l}\text { The obtainment of a certificate } \\
\text { related to the environment }\end{array}$ & $/ 1$ \\
\cline { 2 - 3 } & Conducting an energy diagnostic & $/ 1$ \\
\cline { 2 - 3 } & Improving the energy performances & $/ 1$ \\
\hline
\end{tabular}

The data processing was performed on the basis of a multiple linear regression method to the extent that the endogenous variable (to explain), the score on sustainable development is a continuous quantitative variable.

\section{Results Analysis:-}

Before presenting the different results of our study, it should be stated that our goal is oriented towards three levels:

- The measurement of innovation;

- The measurement of integration in a sustainable development approach ;

- The measurement of the correlation between a sustainable development approach and innovation.

The sample companies are divided into four sectors: Services (1), agri-food (2), industry (3), trade (4) and other (5). According to the study, it appears that $35 \%$ of SMEs say they have developed at least one innovation (Table 2). 
Table 2: Distribution of SMEs in terms of variables

\begin{tabular}{|l|l|l|l|}
\hline Variables & Modalities & The number "n" & Frequency "fi" \\
\hline SC-IN & 0 & 26 & 0,65 \\
& 1 & 8 & 0,2 \\
& 2 & 3 & 0,075 \\
& 3 & 2 & 0,05 \\
SME-IN & 4 & 1 & 0,025 \\
\hline SEC-ACT & 0 & 26 & 0,65 \\
& 1 & 14 & 0,35 \\
\hline TOTAL & 1 & 8 & 0,2 \\
& 2 & 12 & 0,3 \\
& 3 & 6 & 0,15 \\
& 4 & 4 & 0,1 \\
& 5 & 10 & 0,25 \\
\hline
\end{tabular}

According to this study, it is clear that only 3 companies are approaching the theoretical average of 5 and 18 company have a score above the average of the sample 2,167 (Table 3). These results show the inadequacy of the social actions undertaken by companies. However, they confirm a decision awareness of social responsibility by the economic actors.

\begin{tabular}{|l|l|}
\hline Marks_10 & The number "n" \\
\hline 0,75 & 3 \\
1,11 & 6 \\
1,48 & 8 \\
1,85 & 7 \\
2,2 & 5 \\
2,6 & 2 \\
3,2 & 3 \\
3,25 & 2 \\
4,07 & 1 \\
4,8 & 1 \\
5,18 & 1 \\
6,66 & 1 \\
\hline
\end{tabular}

The results of this study strongly suggest that the implementation of a relative approach to sustainable development is favorable to the development of innovations. Furthermore, we note that companies with the highest ratings from a sustainable development perspective are also the most innovative. The companies that scored high in terms of social and environmental shares initiation are those which develop the greatest number of innovations that achieve the largest turnovers.

\section{Conclusion:-}

Through this study, we can confirm that there is a double link between innovation and sustainable development. Indeed, the establishment of sustainable development is positively related to innovation not only the fact or not to innovate but also by the number of innovations and areas of innovation affected.

These results were already mentioned by the model Mc Gregor and Fontrodona (2008), which states the existence of a "virtuous circle" between CSR and innovation in companies. During the implementation of the survey, innovation and sustainable development were measured independently of each other in terms of the data we used. A positive relationship between these two parameters appears very significant. Sustainable development is increasingly present in innovative companies in the "Agribusiness" sector.

The commitment to sustainable development is expressed by an innovative behavior, but it is also interesting that innovative companies are those that are heavily involved in CSR However, the data collected does not identify the values that have guided as much the innovations as the commitment to sustainable development which does not fully 
validate the assumptions of McGregor and Fontrodona (2008). However, it is important to know how companies innovate while remaining a sustainable development strategy to identify the most appropriate accompanying measures.

\section{Bibliography:-}

1. Becquet R., et Mothe C. (2010), Exploring the relationship between CSR and innovation: A comparison betwenn small and large-sized Franch companies, Revue Sciences de Gestion, n ${ }^{\circ} 80$, pp. 101-119.

2. Berger-Douce, S. (2011), Le développement durable, un levier d'innovation pour les PME? ; Revue française de gestion, Vol. 6, no. 215, p. 147-166.

3. Bouvier A. (2010), Les sociétés innovantes de 10 salariés ou plus - Quatre sur dix entre 2006 et 2008, Insee Première, $n^{\circ} 1314$, p.4.

4. Burger-Helmchen T. et Frank L. (2011), La création de rentes : une approche par les capacités dynamiques, Innovations, n॰35 (2011/2), pp. 89-111.

5. Capron M. et Quairel-Lanoizelee F. (2007), La responsabilité sociale d'entreprise, Editions La Découverte, Collection Repères, Paris, 122 p.

6. Chesborough H. (2003), Open Innovation: The new imperative for creating and profiting from technology, Boston, MA/ Harvard Business School Press.

7. Cleff, T. and K. Rennings (1999), Determinants of Environmental Product and Process Innovation, European Environment 9 (5), 191-201.

8. Commission of the European Communities (2002), Corporate Social Responsibility: a Business Contribution to Sustainable Development, COM $(2002)^{\circ} 347$ final, p.24.

9. Conceição P., Heitor M.V., Vieira P.S. (2006), Are environmental concerns drivers of innovation? Interpreting Portuguese innovation data to foster environmental foresight, Technological Forecasting \& Social Change, 73, pp. 266-276.

10. Del Brio J.A, et Junquera B.( 2003), A review of literature on environmental innovation management in SMEs: implication for public policies, Technovation, 23, 939-948.

11. Galliano D., Garedew L., Magrini M.B. (2011), Les déterminants organisationnels de l'innovation produit : les spécificités des firmes agroalimentaires françaises, pp. 50-68 in DGCIS( ed). L'innovation dans les entreprises : moteurs, moyens et enjeux.

12. Gardet E. et Mothe C. (2010), Le rôle des ressources dans la dépendance du pivot au sein de réseaux

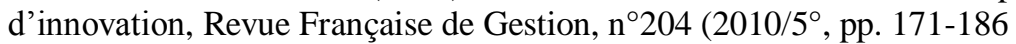

13. Prahalad C.K., Hamel G. (1990), The Core Competencies of the Corporation, Harvard Business Review, vol. $68, n^{\circ} 3$.

14. Hart S.(1995), A Natural-Resource-Based View of the firm, Academy of Management Review, Vol. 20, ${ }^{\circ} 4$, pp. 986-1014.

15. Horbach, J. (2008), Determinants of Environmental Innovation - New Evidence from German Panel Data Sources, In: Research Policy 37 (2008), pp.163-173.

16. Ingham M. (2011), Vers l'innovation responsable ; pour une vraie responsabilité sociétale, Bruxelles : Ed. De Boeck.

17. Le Bas C., Poussing N., Haned N. (2010), Innovation, leadership technologique et comportements de responsabilité sociale. Une exploration sur données d'entreprises, Economies et Sociétés, série " Dynamique technologique et organisation », W, n ${ }^{\circ} 12,8 / 2010$, pp. 1363-1385.

18. Lefebvre, E., L.-A. Lefebvre et S. Talbot. 2003, Determinants and impacts of environmental performance in SMEs, R\&D Management 33 (3), pp.263-83.

19. Lengnick-Hall C.A. (1992), Innovation and competitive advantage : What we know and What we need to learn, Journal of Management, $18:$ pp. 399-429.

20. Masero J., Mirouse B., Amorich S. (2011), Dépenses d'investissement antipollution des industries agroalimentaires - Les choix d'investissement dépendent de l'activité, Agreste Primeur, n 257, p.4.

21. Mathieu A. (2010), Développement durable et innovation: dépasser l'antagonisme pour une complémentarité au service de la performance globale, pp. 159-181 in E. Reynaud ed Stratégies d'entreprises et développement durable, L'Harmattan.

22. Mathieu A., Soparnot R. (2007), L'appropriation du concept de développement durable en entreprise : un générateur d'innovation, Communication à la XVIème Conférence Internationale de Management Stratégique, Montréal, 6-9 juin 2007.

23. Mowery D.C., Oxley J.E., Silverman B.S.(1998), Technological overlap and interfirm cooperation: implications for the resource-based view of the firm, Research Policy, $\mathrm{n}^{\circ} 27$, pp. 507-523. 
24. Nidumolo R., Prahalad C.K., Rangaswami M.R. (2009), why sustainability is now the key driver of innovation? Harvard Business Review, September 2009.

25. Noci, G. et R. Verganti (1999). Managing «green » product innovation in small firms, R\&D Management, 29 : $1, \mathrm{pp} .3-15$.

26. OCDE (2010), L'éco-innovation dans l'industrie : favoriser la croissance verte, OCDE, p.304.

27. Pavelin S., Porter L.A. (2007), The corporate social performance content of innovation in the U.K., Journal of Business Ethics, vol. 80, n 4 , pp. 711-725.

28. Porter, M. E., and M. R. Kramer, (2006), Strategy and Society: The Link Between Competitive Advantage and Corporate Social Responsibility, Harvard Business Review, vol., $n^{\circ}$ p. 78-92.

29. Teece, D. J., G. Pisano, (1994), The dynamic capabilities of firms: An introduction. Indust. Corporate Change 3(3), pp.537-556.

30. Temri L. (2011), Innovations technologiques environnementales dans les petites entreprises: proposition d'un cadre d'analyse, Innovations. Cahiers d'économie de l'innovation. N ³4, pp 11-36.

31. Terlier A. (2009), Le développement durable dans les PMI de l'agroalimentaire, Paris : CROCIS -CCIP.

32. Wernerfelt, B. (1984), A resource-based view of the firm, Strategic Management Journal, vol. 5, pp.171-180. 